
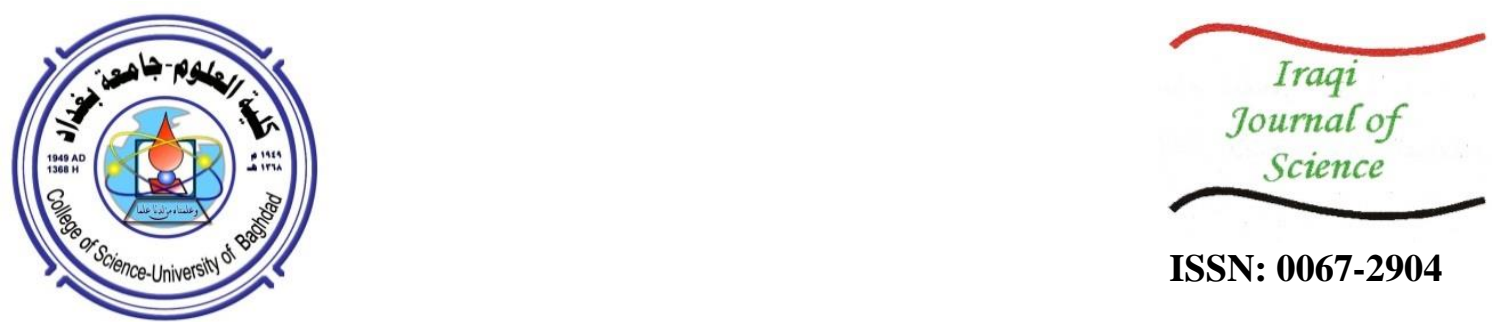

ISSN: 0067-2904

\title{
Calcareous Nannofossil Biostratigraphy and Ostracoda Paleoecology of Hartha Formation from Balad (1) well, Central Iraq
}

\author{
Omar Ahmed Al-Badrani ${ }^{\text {* }}$, Faris Nejris Hassan ${ }^{2}$, Mahfoudh Abdulla Al-Hadeedy ${ }^{1}$ \\ ${ }^{I}$ Department of Geology, College of Science, Mosul University, Iraq \\ ${ }^{2}$ Department of Applied Earth Science, College of Science, Tikrit University, Iraq
}

Received: 26/2/2021

Accepted: 23/6/2021

\begin{abstract}
Seventeen samples of Hartha Formation in Balad (1) well, central Iraq, are studied on the basis of stratigraphic ranges of the recorded calcareous nannofossils for twenty species belonging to twelve genera. The studied section reveals three biozones arranged from oldest to youngest as follows; (1) Calculites ovalis Interval Biozone (CC19), (2) Ceratolithoides aculeus Interval Biozone (CC20), (3) Quadrum sissinghii Interval Biozone (CC21). These Biozones are correlated with other calcareous nannofossils biozones from both local and regional sections, leading to conclude the age of the Middle Campanian.

Rerecorded eighteen ostracode species that belong to eleven genera are identified, all of which were previously recorded from Iraq and adjacent regions. The occurrence of these species leads to conclude a continental shelf environment, while they are typical of inner shelf-outer shelf depth.
\end{abstract}

Keywords: Nanno-biostratigraphy, Ostracoda paleoecology, Cretaceous, Iraq.

\section{الطباقية الحياتية لمتحجرات النانو الكلسية والبيئة القديمة للاوستراكودا لتكوين الهارثة من بئر بلد(1)

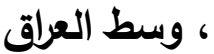

\footnotetext{
عمر احمد البدراني 1* وفارس نجرس حسن 2 و محفوظ عبدالله الحديدي 1 الارئ

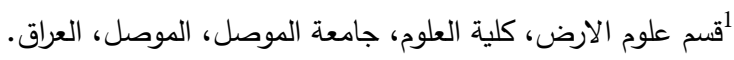

2قسم علوم الارض، كلية العلوم، جامعة تكريت، صلاح الدين، العراق، العرداق.

الخلاصة

درست سبعة عشر نموذجا من تكوين الهارثة في بئر بلد(1) وسط العراق، وبالاعتماد المديات الجيولوجية

لعشرين نوع العائدة لاثنا عشر جنسا من متحجرات النانو الكلسية تم تحديد ثلاثة انطقة حياتية هي من الاقدم

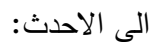

(1) Calculites ovalis Interval Biozone (CC19) Part, (2) Ceratolithoides aculeus Interval Biozone (CC20), (3) Quadrum cf. sissinghii Interval Biozone (CC21) Part.

قورنت هذه الانطقة الحياتية بمثيلاتها المحلية والعالمية بالاستاد لها تم تحديد عمر الكامبانيان الاوسط لهذا

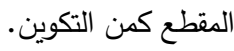

"Email: omarbadrani@uomosul.edu.iq 


$$
\begin{aligned}
& \text { كما سجلت ثمانية عشر نوعا من متحجرات الاوستراكودا تعود الى احد عشر جنسا، قورنت بمثلاتها المحلية } \\
& \text { والعالمية وتم استتاج بيئة الرف وبالتحديد ضمن الرف الاوسط والخارجي بأعماق تتراوح ما بين (30-200) } \\
& \text { مترا. }
\end{aligned}
$$

\section{Introduction}

The Hartha Formation was first described By Rabanit, who described the formation at the type section in well Zubair-3 well, between depths 1704.3-1833.2 m. and about $129 \mathrm{~m}$. in thickness. It consists of organic detrital glauconitic limestone with grey marl and green shale, where the limestone is strongly dolomitized in some places [1].

The Hartha Formation was deposited in the Upper Cretaceous sedimentary cycle within a shallow marine to lagoon environment. The sediments were spread in central and southern Iraq [2,3]. Hartha Formation (Late Campanian-Maastrichtian) is one of the important formations deposited during the upper Cretaceous. The formation includes important carbonate reservoirs that are producible in central and southern Iraq. It acquired its importance because of the presence of quantities of hydrocarbon. The study area is located in Balad Oilfield within Salah Al-Din governorate in central Iraq, $9 \mathrm{~km}$ south of Balad and about $80 \mathrm{~km}$ northwest of Baghdad (Figure 1). The location, identified with the UTM, has the coordinates of N: $3755165.5 \mathrm{M}$ and E: $418349.5 \mathrm{M}$. Tectonically, the formation was first described, in its type section, in the well of Zubair (3) in the Zubair field, southern Iraq. It consists of fossiliferous limestone, marl, and shale and composed of organic detritaland glauconitic limestones with grey and green shaly interbeds [2]. In a study of sediments and reservoir of the Hartha and Saadi formations in the Qayarah field in northern Iraq, the formation was divided into three major microfacies and deposits in the inner, middle, and outer shelf environments [1].

The studied section is located in central Iraq (Figure 1), lying at the Unstable Shelf of the Iraqi tectonic units[4]. The studied section was obtained from Balad well No.1, Central Iraq, being between 1672 and $2115 \mathrm{~m}$ in depth and about $443 \mathrm{~m}$ in thickness.

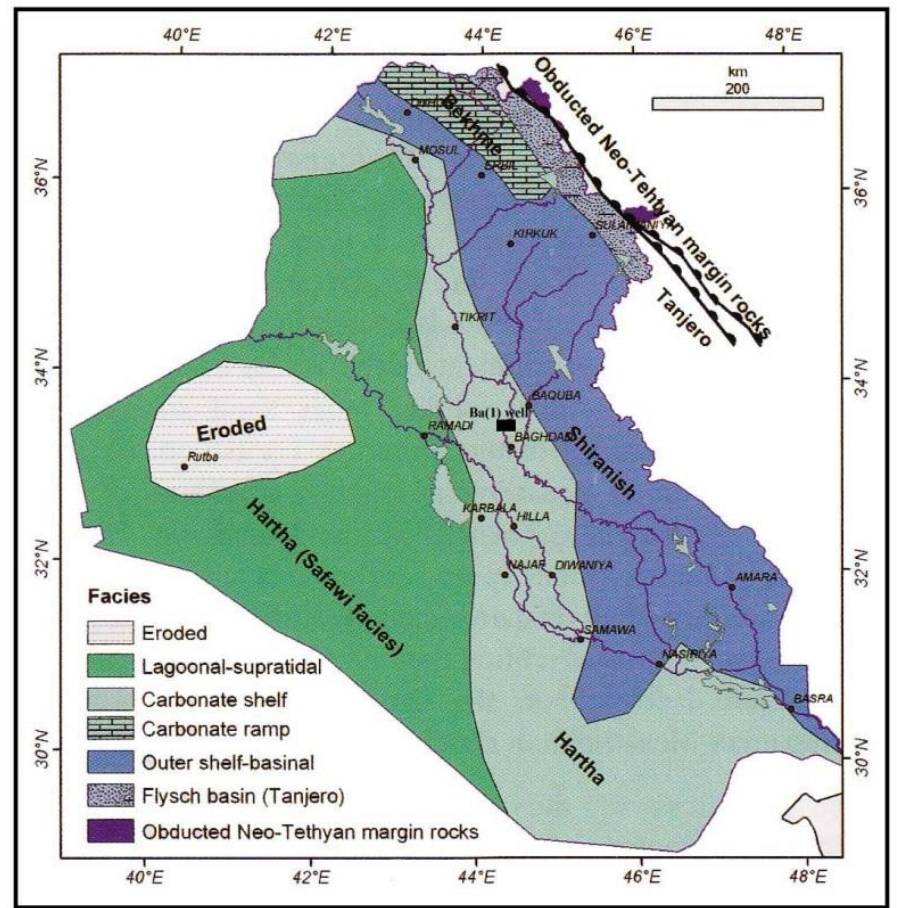

Figure 1- Paleogeographic map locateing Balad (1) well, Central Iraq [2] 


\section{Materials and methods}

Seventeen samples of limestone were selected for studying the calcareous nannofossils, using the thin section which was examined under transmitted light microscope. The calcareous nannofossils were extracted by using the method $(\mathrm{H})$ described previously[5]. It is an extraction method for microfossils that can be properly examined after being extracted from the rocks. Each paleontologist tends to have favorite methods for these purposes. The sample preparation involved decanting and preparation of smear slides of calcareous nannofossils using a small amount of the disaggregated sample. The sample was placed in distilled water and a drop of cellosize was added to act as a dispersant. The cover slip was left to dry on a warm hotplate. To make permanent mounts, the slide and residue were allowed to dry at a low temperature away from possible sources of contamination. A drop of mounting medium (e.g. Canada balsam) was placed on a clean cover slip and the residue was removed. The sample was allowed to dry before examining it with transmitted light. The Ostracoda were studied by reflected light microscope.

\section{Results and Discussion}

\section{I- Calcareous Nannofossils}

1 - Systematic Paleontology

The aim of systematic classification is to provide images of the notable calcareous nannofossils from the Hartha Formation in $\mathrm{Ba}(1)$ well, Central Iraq, and to describe the twenty species. The material and images are stored in the Department of Geology, Science College, University of Mosul (Figure 2).

2 - Nannobiostratigraphy (Figures.3,4)

Depending on the stratigraphic distribution of the recorded species, three Biozones were identified; these are :

1- Calculites ovalis Interval Biozone (CC19)

Definition: Interval of Calculites ovalis, bounded from the last occurrence of Marthasterites furcatus (Deflandre and Fert) Deflandre to the first occurrence of Ceratolithoides aculeus Stradner.

Thickness: 165 meters.

Discussion: This biozone was correlated with the Calculites ovalis biozone, by Sissingh [6], which is aged Middle Campanian. It was also correlated with Brosonia parca by Roth[7] and Doven [8]; therefore, we suggest the early Middle Campanian for this biozone [9].

2- Ceratolithoides aculeus Interval zone (CC20)

Definition: Interval Ceratolithoides aculeus, bounded from the first occurrence of Ceratolithoides aculeus Stradner to the first occurrence of Quadrum sissinghi Perch-Nielsen. Thickness: 150 meters.

Discussion: This biozone was correlated with the Ceratolithoides aculeus biozone by Sissingh [6], that is aged Middle Campanian. It is also correlated with Ceratolithoides aculeus by Roth [7] and Doven [8]; therefore, we suggest the middle Middle Campanian for this biozone [9].

\section{3 - Quadrum sissinghii Interval Biozone (CC21)}

Definition: Interval from the first occurrence of Quadrum sissinghi Perch-Nielsen to the first occurrence of Quadrum trifidum (Stradner and Papp) Manivit et al..

Thickness: 135 meters.

Discussion: This biozone was correlated with the Quadrum sissinghii biozone by Sissingh [6], that is aged Middle Campanian. It is also correlated with Quadrum sissinghii by Roth [7] and Doven [8]; therefore, we suggest the late Middle Campanian for this biozone [9]. 

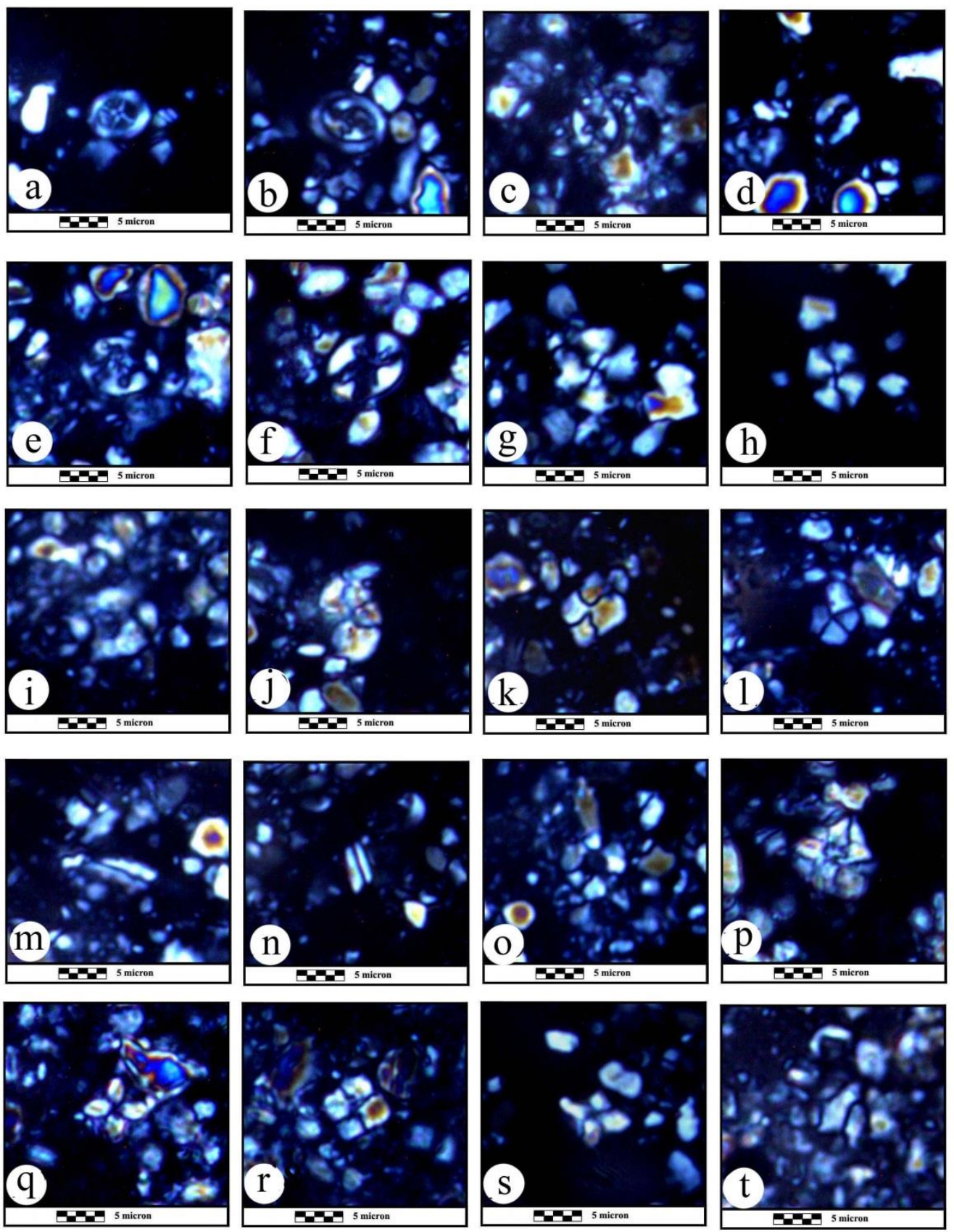

Figure 2-Cross-polarized photos of significant calcareous nannofossil taxa from Hartha Formation. (a) Chiastozygus litterarius; (b) Glaukolithus diplogammus; (c) Eiffellithus eximius; (d) Eiffellithus gorkae; (e) Eiffellithus parallelus; (f) Eiffellithus turriseiffeli; (g) Watznaueria barnesae; (h) Watznauria biporta; (i) Broinsonia parca; (j) Calculites obscure; (k) Calculites ovalis; (l) Braarudosphaera batilliformis; (m) Lithraphidites acutus; (n) Lithraphidites sp.; (o) Eprolithus sp.; (p) Micula concave; (q ) Micula staurophora; (r) Quadrum gartneri; (s) Quadrum cf. sissinghii; (t) Ceratolithoides aculeus. 


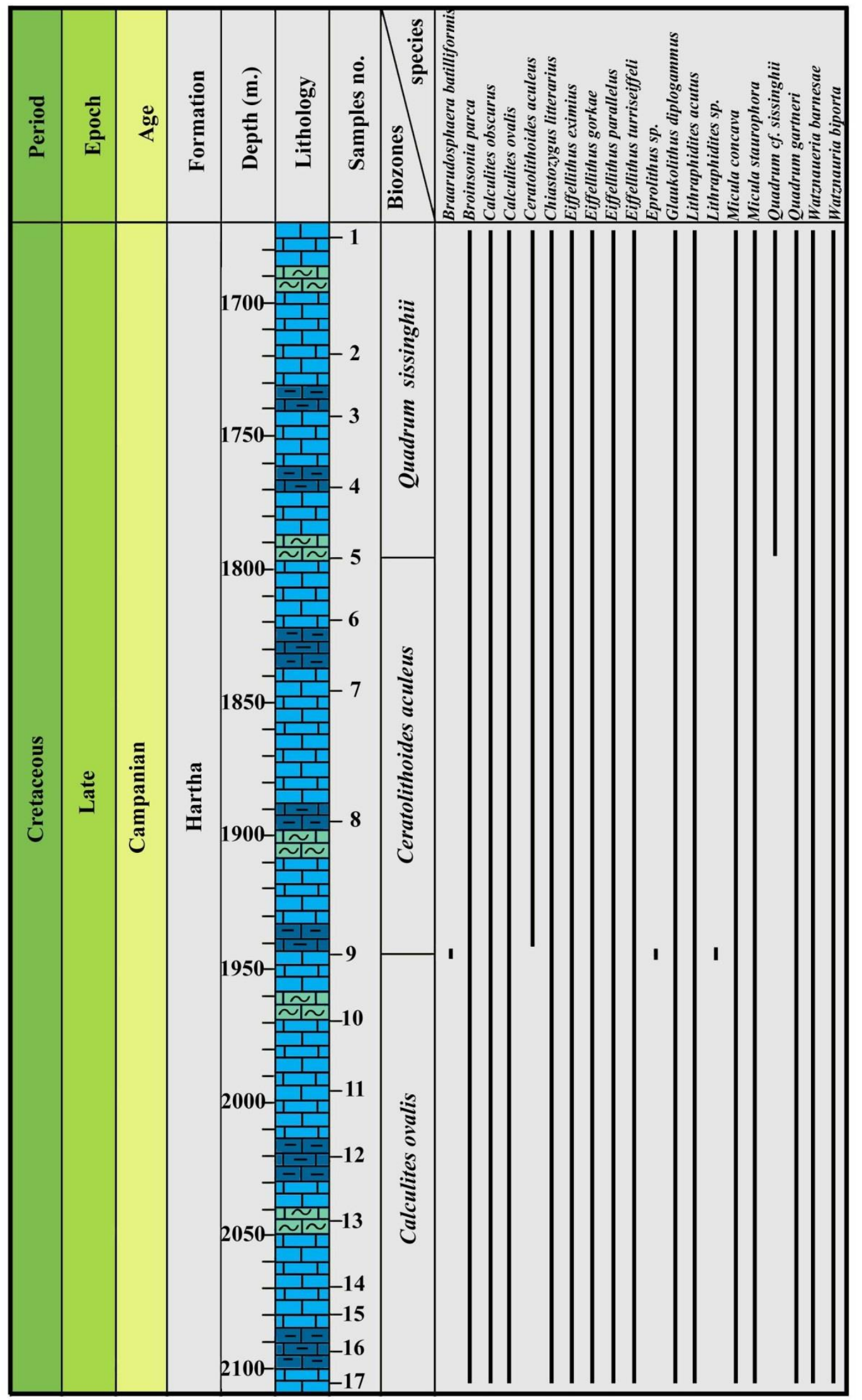

Figure 3-Biostratigraphic chart for calcareous nannofossils of Hartha Formation, Ba (1) well, Northern Iraq. 


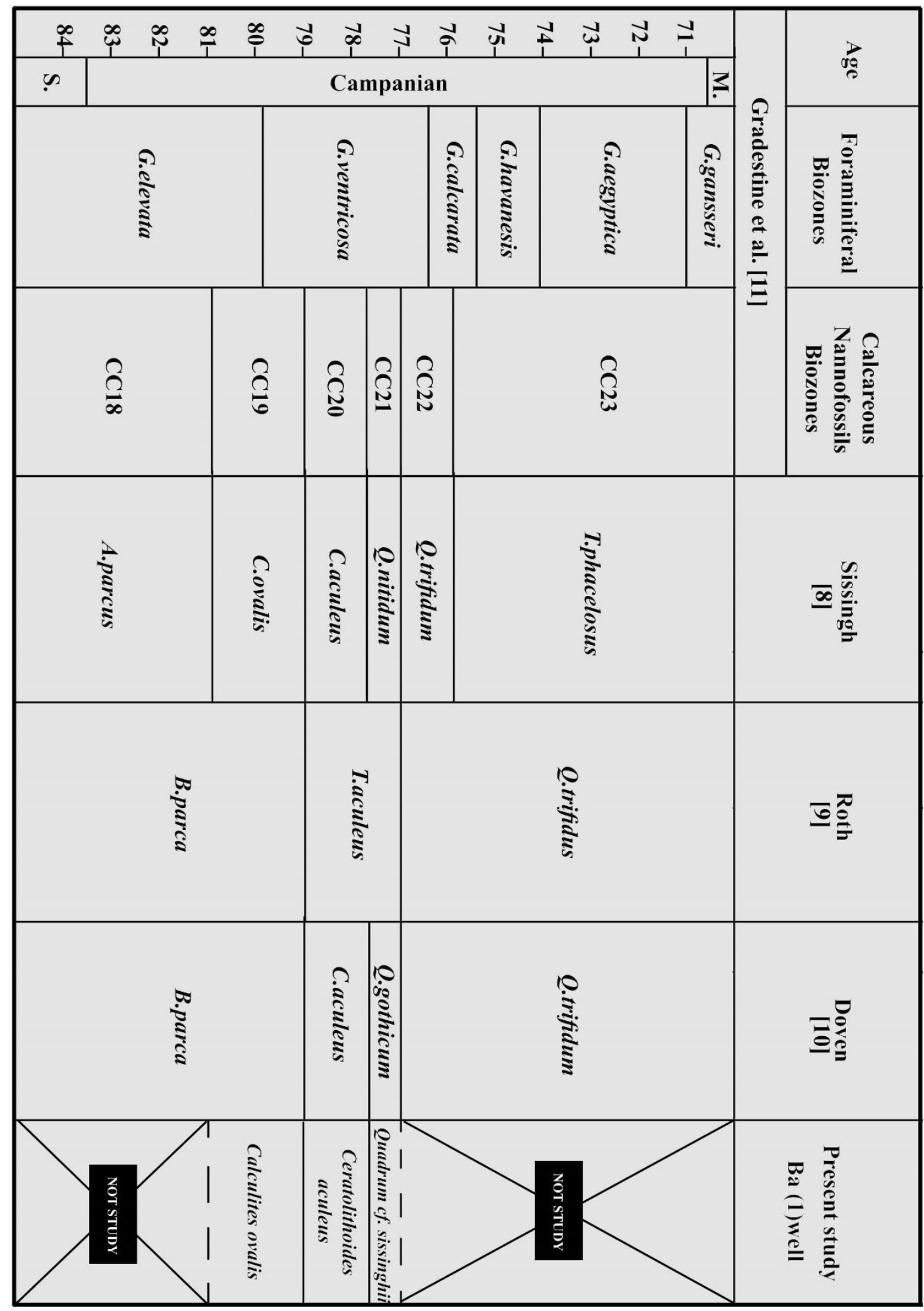

Figure 4-Corrllation chart for the Campanian calcareous nannofossils from Hartha Formation, Ba (1) well, Northern Iraq.

\section{II- Ostracoda}

\section{1 - Systematic Paleontology}

The aim of systematic classification is to provide images of the notable Ostracoda from the Hartha Formation in $\mathrm{Ba}$ (1) well, Central Iraq, and to describe the eighteen species. The 
material and images are stored in the Department of Geology, Science College, University of Mosul (Figures. 5 and 6).

\section{2 - The ostracoda as environmental indicators}

The paleoecological interpretation of the recorded ostracodes is mostly depending on the comparison of our data with other bathymetric distribution patterns established in Iraq and elsewhere in the Middle East and North Africa.

a- Genus Cytherella indicates shelf environment [10, 12], middle outer shelf [11], and low oxygen level [13].

b- Genus Uroleberis indicates outer shelf environment [14], middle to outer shelf [15], inner shelf, or lagooned environment [16].

c- Genus Parakrithe indicates inner-outer shelf environment [10, 12], deep water marine [17], inner- outer shelf environment [16], and outer shelf environment [18].

d- Genus Pontocyprella indicates outer shelf environment [10], deep part of outer shelf to upper part of upper bathyal open sea, outer shelf environment [19], and inner- outer shelf environment [12].

e- Genus Hermanites indicates middle-outer shelf environment, shallow marine environment [20], and inner shelf environment [11].

f- Genus Bairdia indicates inner-outer shelf environment [10], middle-outer shelf environment [21], and middle- outer shelf environment [11].

g- Genus Paracypris indicates inner-outer shelf environment [10, 12], upper slope (200-500 m.) [22], middle-outer shelf environment, and inner-deep shelf environment [11].

h- Genus Brachycythere indicates inner-middle shelf environment [17, 23, 16, 12] and inner shelf environment [24].

i- Genus Peloriops indicates inner- outer shelf environment [24].

j- Genus Bythocypris indicates marine (bathyal) environment [17] and outer shelf environment [23].

k- Genus Bairdoppilata indicates outer shelf environment [23].

\section{3 - The ostracoda assemblages as environmental indicators}

a- The occurrence of the assemblage Cytherella and Pontocyprella indicates outer shelf environment [25].

b- The association of Cytherella, Bairdia, and Paracypris indicates shelf environment [26].

c- The presence of Cytherella, Bairdia, and Pontocyprella indicates middle shelf environment [27].

d- The assemblage of Cytherella, Bairdia, Hermanites, and other ornamented species indicates outer shelf environment [17, 28].

According to Singh [29], the assemblage of Cytherella, Bairdia, Hermanites, and Uroleberis with ornamented species is a characteristic to inner shelf taxa.

e- The association of Bairdia and Parakrithe indicates shallow marine inner shelf to outer shelf depth [17] and inner shelf- outershelf [10].

f- The occurrence of the assemblage of Krithe, Parakrithe, and Pontocyprella with ornamented species is a characteristic to outer shelf environment [10].

g- According to Morsi and Wendler [10], the assemblage of Cytherella, Bairdia, Paracypris, and Peloriops is characteristic to open marine shelf texa.

Ahmad et al. [30] stated that when the ecology at the species level is unknown or overlapped, a certain limitation is placed upon the interpretation of paleoecology based on the generally accepted habitat of certain genera.

The diversity of ostracods is an important indicator for determining the paleoecology in marine settings. Higher ostracod diversities are more common in the shelf environment [12].

h- The occurrence of the smooth species of Cytherella, Bairdia, Bairdoppilata, Bythocypris, Pontocyprella, and Parakrithe generally indicate deep marine environment and outer shelf to 
upper slop. The association with the ornamented and eye-tubercle species of Brachycythere, Hermanites, and Peloriops generally refers to middle to outer shelf environment; therefor, the assemblages of ostracoda from Hartha Formation were found to be characteristic for continental shelf environment and they are typical for inner shelf-outer shelf environment.

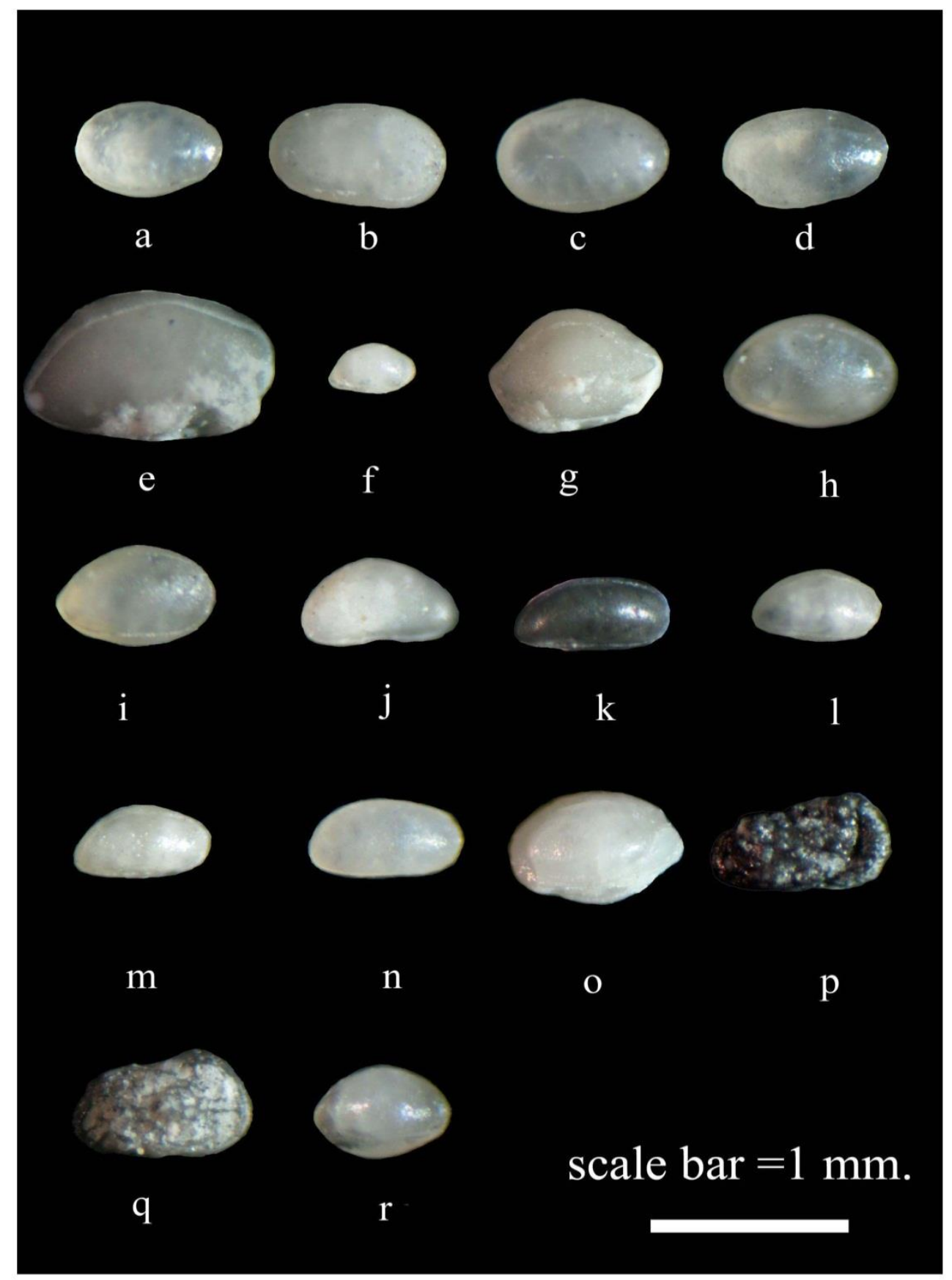

Figure 5-Cross-polarized photos of significant Ostracoda taxa from Hartha Formation. (a)Cytherella iraqiensis; (b)Cytherella mushoraiensis; (c)Cytherella ovate; (d)Cytherella postangulata; (e)Bairdia eocaenica; (f)Bairdia heijransis; (g)Bairdia poddari; (h)Bairdia khurmalensis; (i)Bairdoppilata jaswanti; (j)Bythocypris mianica; (k)Paracypris paramaghaghaensis; (1)Pontocyprella eocaenica; (m)Pontocyprella recurve; (n) Parakrithe crolifa; (o)Brachycythere ghalaisanaensis; (p)Peloriops (Peloriops) ibniraki; (q)Hermanites soliporosa; (r)Uroleberis iraqensis. 


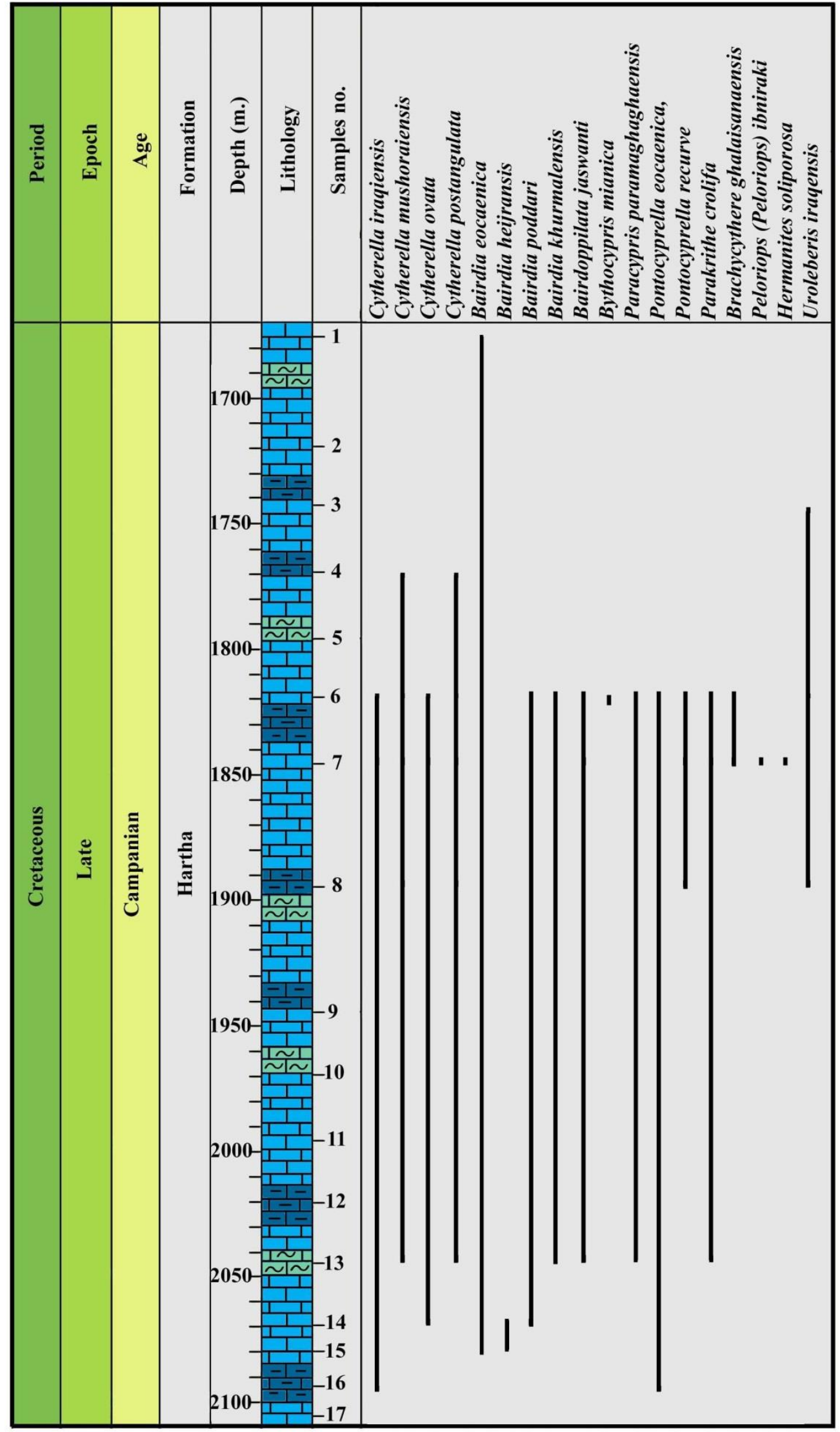

Figure 6-Biostratigraphic chart for Ostracoda of Hartha Formation, Ba (1) well, Northern Iraq. 


\section{Conclusions}

On the basis of stratigraphic ranges of the recorded calcareous nannofossils, three biozones were determined in Hartha Formation. They are arranged from the oldest to the youngest as follows: 1- Calculites ovalis Interval Biozone (CC19) Part, 2- Ceratolithoides aculeus Interval Biozone (CC20), 3- Quadrum cf. sissinghii Interval Biozone (CC21) Part.

These Biozones are correlated with other calcareous nannofossil biozones from both local and regional sections, leading to conclude the age of Middle Campanian. Also, eighteen ostracode species that belong to eleven genera were identified, all of them previously recorded from Iraq and adjacent regions, leading to conclude a continental shelf environment. It is also concluded that they are typical of inner shelf-outer shelf environment.

\section{Acknowledgments}

The authors are very grateful to the University of Mosul, College of Science for the provision of facilities, which helped to improve the quality of this work.

\section{References}

[1] Bellen, R.C. van, Dunnington, H.V., Wetzel, R. and Morton, D., Lexique Stratigraphique International. Asie, Iraq, Fasc. 10a, Paris, 1959, 333p.

[2] Jassim SZ, Goff JC Geology of Iraq. Czech Republic, Dolin, Prague and Moravian Museum, Brno, 2006, 341p.

[3] Homadi, B.J and Al-Zaidy ,A.A. "Microfacies Analysis and Basin Development of Hartha Formation in East Baghdad Oil field, Central Iraq". Iraqi Journal of Science, vol. 61, no. 11, pp. 2978-2989, 2020.

[4] Buday, T. and Jassim, S.Z., The regional geology of Iraq, v.2., Tectonism, Magmatism and Metamorphism. Dept. S.E. Geol. Surv. And Miner. Invest., Baghdad, 1987, 352p.

[5] Armstrong, H. and Brasier, M. Microfossils Black well publishing, 2005, 296p.

[6] Sissingh W., "Biostratygraphy of Cretaceous Calcareous nannoplankton". Geologie en Mijnbouw. vol. 56, no. 1, pp. 37-65, 1977.

[7] Roth, P. H., Calcareeous nannoplankton biostratigraphy and oceanography of the Northwestern Atlantic Ocean. In Benson, W. E., Sheridan, R. E., et. al., Initial reports of the Deep sea drilling project. Washington (U.S. Government Printing office), vol. 44, pp. 731- 759, 1978.

[8] Doeven, P. H., "Cretaceous nannfossil stratigraphy and paleoecology of the Canadian Atlantic margin". Geological survey of Canada Bulletin, vol. 356, pp. 1-70, 1983.

[9] Gradstein, F. M., Ogg, J. G.., Schmitz, M.D. and Ogg, G. M. The geological time scale 2012, Elsevier, vol.2, 2012, 1144p.

[10] Morsi, A.M., Scheibner, C., "Paleocene-Early Eocene ostracodes from the Southern Galala Plateau (Eastern Desert, Egypt): taxonomy, impact of paleobathymetric changes". Revue de Micropaléontology, vol, 52, pp. 149-192, 2009.

[11] Hamdi, A.A., Dhahri, F., Jomaa-Salmouna, D., Ben Ismail-Lattrache, K. and Ben Chaabane, A., "Quantative analysis and paleoecology of Middle to Uppe Eocene Ostracodsfrom Jebel Jebil, central Tunisia". Revue de Micropaléontologie, vol. 59, no. 2016, pp. 409-424, 2016.

[12] Hewaidy, A.A., Morsi, A.M., \& Samir, A., "Maastrichtian-Paleocene Ostracoda from Teneida section, Dakhla Oasis, Western Desert, Egypt: Systematics, biostratigraphy, paleobathymetry and paleobiogeography". Jour. of African Earth Sciences, vol. 174, no. 2021, 104072, pp. 1 - 22, 2021.

[13] Whatley, R.C. "The platycopid signal : a means of detecting kenoxic events using Ostracoda". Journal of Micropaleontology, London, vol. 10, pp. 181-183, 1991.

[14] Neal, T.W., Ostracods and paleosalinity reconstruction. In: De Decker, P., Colin, j.p. and Peypouquet, J.P. (eds.); Ostracoda in the Earth Sciences. Elsevier, Amsterdam, Oxford, New York, Tokyo. pp.126-155, 1988.

[15] Zhao, Q. and Wang, P. , Distribution of modern ostracoda in the shelf seas off China. In: Hanai, T., Ikeya, N. and Ishizaki, K. (eds.), Evolutionary Biology of Ostracoda. 1988, pp. 805-819, Elsevier. 
[16] Bassiouni, M.A. A. and Luger, P., "Maastrichtian to Early Eocene Ostracoda from south Egypt. Paleontology, Paleoecology, Paleobiogeography and Biostratigraphy". Berliner Geowissenschaftliche Abhandlungen. Berlin, (A), vol. 120, no. 2, pp. 755 - 928, 1990.

[17] Van Morkhoven, F.P.C., Post-Paleozoic Ostracoda. Elsevier Pub. Comp., Amsterdam, vol. 2, $1963,478 \mathrm{p}$.

[18] 18. Al-Sheikhly, S.S.J. and Kamil, A.I., "Ostracoda as a paleoecological indicators for the Maastrichtian - Upper Eocene succession in North an Western Iraq". Iraqi Jour. of Science, vol. 57, no.2B, pp. 1227-1237, 2016.

[19] Keen, M.C., Al-Sheikly, S.S.J., Elsogher, A, and Gammudi, A.M., Tertiary ostracods of North Africa and Middle East. In: Simmons, M. D., (ed.), Micropal. and hydrocarbon exploration in the Middle East, 1994.

[20] Nazik, A., "Macropaleontological (ostracoda and foraminifera) Investigation of Tertiary Sequence of Darendes basin". Geol. Bull. Turkey, vol. 36, pp. 13-36, 1993.

[21] El-Elewa, A.M.T., "Paleobiogeography of Maastrichtian to Early Eocene ostracoda of North and West Africa and the Middle East". Micropal. vol.48, no.4, pp.391-398, 2002.

[22] Pezelj, D., Sremac, J. and Sokac, A., "Palaeoecology of the Late Badenian foraminifera and ostracoda from the SW central Paratethys (Medvednica mt.) Coroatia”. Geologia Croatica, vol. 60, no. 2, pp. 139-150, 2007.

[23] El-Nady, H.m Abu-Zied, R., Ayyad, S., "Cenomenian - Maastrichtian ostracoda from Gabal Arif El-Naga anticline, Eastern Sinai, Egypt - Revue de paléobiologi”, Genéve, vol. 27, no. 2, pp. 533 $-573,2008$.

[24] Al-Bashir, J., M., T., Cretaceous Ostracoda of the Superfamily Cytheracea from Iraq. Their Biostratigraphy and Correlation with Adjacent Regions. Ph. D. unpub. Thesis. Univ. Glasgow, $1986,586 \mathrm{p}$.

[25] Zarrago, E. G. and Lazaro, j.R., "Late Cretaceous Ostracode Fauna from the Biscay Synclinorium (Basque Arc, Northern, Spain)". Cour. Forsch. -Inst Senckenberg, vol. 123, pp. 229 -238, 1990.

[26] Rosenfeld, A., Gerry, E. \& Honigstein, A., Jurassic-Cretaceous Non-Marine Ostracods from Israel And Palaeoenvironmental Implications. In : Hanai, T., Ikeya, N. and Ishizaki, K. (eds.), Evolutionary Biology of Ostracoda Its Fundamentals and Applications. Proc. 9th Int. Symp. Ost., Shizuoka, Japan. July August 1985, Elsevier, pp. 659 - 699, 1988.

[27] Dingle, R. V., "The Campanian and Maastrichtian Ostracoda of South- East Arica". Ann. S. Afr. Mus. vol. 85, no.1, pp. 1 - 181, 1981.

[28] Monostori, M., Eocene ostracoda from the Dorog Basin (Northern Transdanubia, Hungary) Akademia Kaido Budapest, pp. 1-214, 1985.

[29] Singh, P. , Paleobiogeography and paleoecology of the Tertiary ostracods of Northwestern India with palaeoceanographic remarks. In; (Hanai, T. Ikeya, N. and Ishizaki, K. edr.), Evolutionary Biology of Ostracoda, its fundamentals and application. Elsevier, pp.619-636, 1988.

[30] Ahmad, M., Neale, J. W., \& Siddiqui, Q.A., "Tertiary ostracoda from the Lindi Area, Tanzania". Bull. Br. Muss. Nat. Hist. (Geol.), vol. 46, no.2, pp. 175 - 270, 1991. 